\title{
Trace elements: adventitious yet essential dietary ingredients
}

\author{
By J. K. Chesters, Rowett Research Institute, Bucksburn, Aberdeen AB2 9 SB
}

Fourteen trace elements, chromium, cobalt, copper, fluorine, iodine, iron, manganese, molybdenum, nickel, selenium, silicon, tin, vanadium and zinc, have been shown to be essential for animals (Reinhold, 1975). Clear evidence of a human requirement exists for only about half of these elements but in these instances the signs of deficiency often correspond closely with those observed in experimental animals. It is likely that most of the elements essential for other mammals are also essential for man, but in the past only two of the trace elements, Fe and I, have been considered routinely in evaluating human diets. The purpose of this contribution is to suggest that deficiencies of the remaining trace elements merit more consideration than they have previously received.

\section{Involvement of trace elements in clinical disorders}

In addition to the classically recognized diseases associated with inadequate intakes of $\mathrm{Fe}$ and $\mathrm{I}$ and the beneficial effects of $\mathrm{F}$ in preventing tooth decay, recent studies have implicated trace element deficiencies and imbalances in a range of clinical disorders. When infants suffering from protein-energy malnutrition were treated with diets based on dairy products, failure to consider the adequacy of their $\mathrm{Cu}$ intakes resulted in hypocupraemia and a range of Cu-responsive symptoms including poor $\mathrm{Fe}$ absorption, neutropenia, demineralization of bone and defective erythrocyte production (Graham \& Cordano, 1969). Deficiencies of both $\mathrm{Cu}$ and $\mathrm{Zn}$ have been reported following total parenteral nutrition of patients with preparations of inadequate trace-element content (Arakawa, Tamura, Igarashi, Suzuki \& Sandstead, 1975; Fleming, Hodges, Smith \& Hurley, 1975; Okada, Takagi, Itakura, Satani, Manabe \& Ilda, 1975; Ricour, Gros, Maziere \& Comar, 1975). Klevay (1975) has suggested that a high $\mathrm{Zn}$ : $\mathrm{Cu}$ ratio in the diet predisposes to coronary heart disease and may be a unifying factor in the wide range of variables which correlate with this condition in epidemiological studies. In the Middle East, $\mathrm{Zn}$ deficiency is at least partially responsible for growth retardation and arrested sexual development in adolescent boys (reviewed in Burch, Hahn \& Sullivan, 1975; Reinhold, 1975). In the USA, clinical abnormalities of taste and smell (idiopathic hypogeusia) have been reversed by $\mathrm{Zn}$ supplementation (Henkin, 1971) and in a study of the normal range of trace element concentrations in hair, Hambidge, Hambidge, Jacobs \& Baum (1972) found a group of children in Colorado with low hair $\mathrm{Zn}$ concentrations. A high proportion of these children showed objective hypogeusia when discovered but taste acuity returned to normal 
after supplementation with $\mathrm{Zn}$ for 3 months. In this study, low hair $\mathrm{Zn}$ concentrations were associated with poor appetite and growth, both prominent features of $\mathrm{Zn}$ deficiency in young animals. $\mathrm{Zn}$ supplementation of patients has also been shown to improve wound healing after surgery (Pories, Henzel, Rob \& Strain, 1967) although possibly only when the patients are initially $\mathrm{Zn}$-deficient (Henkin, 1974). In at least two trials, treatment of patients suffering from maturity-onset diabetes with inorganic $\mathrm{Cr}$ resulted in marked improvement in glucose tolerance in approximately half of the cases investigated (reviewed by Hambidge, 1974). Carlisle (1974) and Schwarz (1974a) have postulated that deficiency of Si may be involved in the aetiology of arthritic conditions and atherosclerosis. Although human trace element deficiencies probably occur only under restricted conditions, there is clearly a need to predict these situations and to determine the effectiveness of measures taken to combat them.

\section{Recommended requirements for the trace elements}

The National Academy of Sciences of the USA (National Research Council, 1974) and a WHO expert committee (WHO, 1973) have recently attempted to define human requirements for the trace elements but concluded that there was not sufficient information available to do so for $\mathrm{Cr}, \mathrm{Mo}, \mathrm{Ni}, \mathrm{Se}, \mathrm{Sn}$ and $\mathrm{V}$. Although often based on incomplete evidence, human requirements have been estimated for $\mathrm{Co}, \mathrm{Cu}, \mathrm{F}, \mathrm{Fe}, \mathrm{I}$ and $\mathrm{Mn}$ and these are set out in Table $\mathrm{I}$ together with the recommended minimum dietary concentrations of the trace elements for rats and chicks, the only species for which extensive information is available. The recommended requirement for $\mathrm{Zn}$ is of particular interest since Sandstead (1973) has suggested that a significant proportion of the population of the USA may well have intakes of $\mathrm{Zn}$ lower than this and 'well-balanced' hospital diets in the USA may provide as little as $5 \mathrm{mg} \mathrm{Zn/d}$ (Osis, Kramer, Wiatrowski \& Spencer, 1972). $\mathrm{Zn}$ deficiency may therefore be more widespread than previously recognized, especially since it is recommended that intakes of $\mathrm{Zn}$ be increased by about 15 $\mathrm{mg} / \mathrm{d}$ during pregnancy and lactation. Most diets provide about $2 \mathrm{mg} \mathrm{Cu} / \mathrm{d}$ (Schroeder, Nason, Tipton \& Balassa, 1966) which appears marginal to satisfy the $\mathrm{Cu}$ requirement of man. There is no evidence that Co has a function in human nutrition other than as a part of vitamin $B_{12}$ and as such it lies outside the scope of the present contribution.

\section{Factors affecting trace element requirements and their assessment}

Values for trace element requirements are not absolute but depend on the age (cf. $\mathrm{Zn}$ requirements given by $\mathrm{WHO}$ (1973)) and physiological state of the subject, as exemplified by the increased requirements during pregnancy and lactation. Additionally they may be influenced by genetic factors, as has been clearly established for the Cu requirements of different breeds of sheep (Wiener \& Field, 1969) and for those of individuals within a single breed of cattle (Mills, Dalgarno \& Wenham, 1976). Consideration should therefore be given to the possibility that, for 
Table I. Recommended dietary allowances of trace elements for normal human adults and minimum dietary concentrations for growing rats and chicks

\begin{tabular}{|c|c|c|c|}
\hline \multirow[b]{2}{*}{ Element } & \multirow{2}{*}{$\begin{array}{l}\text { Human dietary } \\
\text { allowance } \\
\text { (mg/d) }\end{array}$} & \multicolumn{2}{|c|}{$\begin{array}{c}\text { Dietary concentration } \\
(\mathrm{mg} / \mathrm{kg})\end{array}$} \\
\hline & & Rats $\uparrow$ & Chicks $\ddagger$ \\
\hline $\begin{array}{l}\text { Cobalt (as vitamin } \mathrm{B}_{12} \text { ) } \\
\text { Chromium }\end{array}$ & $\underset{\text { nd }}{0.00013}$ & $\begin{array}{l}0.0002 \\
2-5 \mathrm{D}\end{array}$ & $\begin{array}{c}0.0004 \\
\text { nd }\end{array}$ \\
\hline Copper & 2 & 5 & 4 \\
\hline Fluorine & 3 & $2 \cdot 5$ & $I-2 \S$ \\
\hline Iron & 10 & 35 & 80 \\
\hline Iodine & $0.1 \multimap 0.15$ & 0.15 & 0.35 \\
\hline $\begin{array}{l}\text { Manganese } \\
\text { Molybdenum }\end{array}$ & $\begin{array}{c}2-3 \| \\
\text { nd }\end{array}$ & $\begin{array}{l}50^{\circ} \\
<0.02\end{array}$ & 55 \\
\hline Nickel & nd & $0.08 \S$ & $0.08 \S$ \\
\hline Selenium & nd & 0.049 & 0.1 \\
\hline Silicon & nd & $250^{\circ}$ & $250 \S$ \\
\hline Tin & nd & 29 & nd \\
\hline Vanadium & nd & $0.1 \S$ & $0.1 \S$ \\
\hline Zinc & 15 & 12 & 50 \\
\hline
\end{tabular}

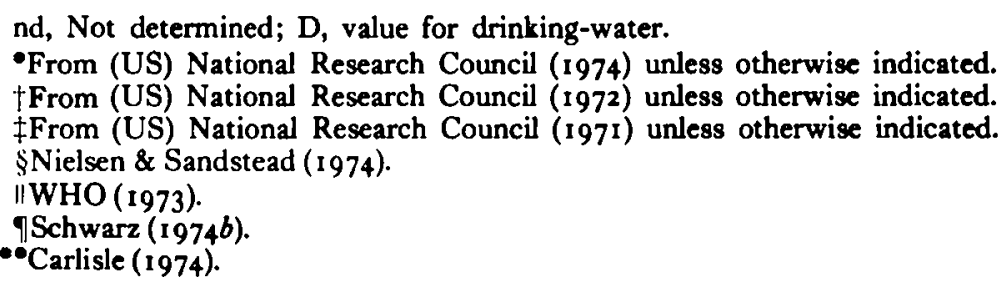

a given trace element, genetic factors may result in a broad distribution of requirements, the extremes of which may already be apparent from the involvement of trace elements in the following conditions. Acrodermatitis enteropathica produces signs similar to those of $\mathrm{Zn}$ deficiency in animals and these can be relieved by $\mathrm{Zn}_{\mathrm{n}}$ supplementation (Moynahan, I974); Menkes' syndrome is associated with impaired absorption of $\mathrm{Cu}$ (Danks, Cartwright, Stevens \& Townley, 1973), and Wilson's disease results in abnormal accumulation of $\mathrm{Cu}$ in tissues (Cartwright, Markowitz, Shields \& Wintrobe, r 960).

The assessment of human trace element requirements has involved two different techniques. For $\mathrm{Fe}$ and $\mathrm{Zn}$, the total daily excretion and accretion of the metals have been estimated together with their fractional availability from diets. Dietary requirements were then deduced from these values (WHO, 1973; (US) National Research Council, 1974). An alternative approach has been to select a process related to the element's function and investigate its variation with dietary intake of the element. With this method, the criterion of assessment can affect the apparent requirement of an animal. Thus Underwood \& Somers (1969) found that while $17.4 \mathrm{mg} / \mathrm{kg}$ diet provided sufficient $\mathrm{Zn}$ for normal food consumption and growth of rams, testicular development and spermatogenesis were significantly improved when diets contained $32.4 \mathrm{mg} \mathrm{Zn} / \mathrm{kg}$. The usefulness of this type of approach therefore depends on the choice of suitable criteria. With I, for which there appears 
to be only a single biological function, estimation of the concentrations of thyroid hormones can provide accurate assessment of I status. In other instances the criteria used have not always been so satisfactory. Blood haemoglobin concentrations usually correlate closely with adequacy of $\mathrm{Fe}$ intake but situations exist where treatment of anaemia in man requires supplementation with $\mathrm{Cu}$ as well as $\mathrm{Fe}$ (reviewed by Mills, 1973a). In adults, low plasma $\mathrm{Cu}$ concentrations are generally indicative of inadequate $\mathrm{Cu}$ intake but the blood of neonates appears to be characteristically low in $\mathrm{Cu}$ as a result of a physiological control which restricts synthesis or survival of caeruloplasmin (Scheinberg, Cook \& Murphy, I954). Normal postnatal development results, however, in a major increase in plasma caeruloplasmin concentrations within the first few months of life so that, while a low plasma $\mathrm{Cu}$ concentration is normal at birth, its failure to increase with age may be an important indication of Cu deficiency (Graham \& Cordano, 1969).

There are also a variety of conditions which result in decreased plasma concentrations of $\mathrm{Zn}$ and usually of $\mathrm{Fe}$ and they are generally associated with elevated plasma $\mathrm{Cu}$ concentrations. These conditions include late pregnancy (Hambidge \& Droegemueller, 1974), women taking oral contraceptives (O'Leary \& Spellacy, 1968; Briggs, Briggs \& Austin, 1971), a variety of infectious and pathological conditions (Halstead \& Smith, 1970; Beisel, Pekarek \& Wannemacher, 1974) and postoperative states (Lindeman, Bottomley, Cornelison \& Jacobs, 1972). The decrease in plasma $\mathrm{Zn}$ concentration occurs despite intakes of $\mathrm{Zn}$ which would normally be considered adequate, and there is not enough evidence available to decide whether a functional deficiency of $\mathrm{Zn}$ exists, whether it could be corrected by supplementation and if so, whether this would be beneficial. In view of the clinical importance of these conditions, experimentation to elucidate these points is urgently required. The corresponding reductions in plasma $\mathrm{Fe}$ concentration have been more extensively studied but generalizations seem impossible. Low plasma $\mathrm{Fe}$ during pregnancy probably indicates a functional deficiency which may be beneficially overcome by supplementation (Hytten \& Leitch, 1964) but $\mathrm{Fe}$ administration during infection has generally been deleterious (Sussman, 1974).

\section{Assessment of dietary supply of a trace element}

The ability of a diet to provide the requirement for a trace element depends on three factors, the amount ingested, the biological effectiveness of the form of the element ingested and the presence of other factors in the diet which affect its availability. Assessments of the first two of these factors are subject to errors associated with analytical techniques. The precision and sensitivity of the methods employed are frequently inadequate as limits of detection are approached, the specificity of the methods used is not always known and contamination during sample preparation can be a problem (Mertz, 1975). Volatility of the element or its compounds has also been a major source of error in trace element analysis. When human tissue was prepared for analysis by dry ashing at $45^{\circ}$, Sn was not universally present and was not therefore considered to be an essential element for man (Schroeder, Balassa \& Tipton, 1964). Subsequent studies showed, however, 
that almost all $\mathrm{Sn}$ compounds are volatile well below this temperature, that $\mathrm{Sn}$ is an essential trace element for rats and chicks and that with suitable lowtemperature sample preparation it is found in concentrations around $I \mu \mathrm{g} / \mathrm{g}$ in several tissues of man (Schwarz, 1974b). The extreme volatility of chromyl chloride and some biological complexes of $\mathrm{Cr}$ can also lead to losses of $\mathrm{Cr}$ during sample preparation; indeed, the problems associated with trace element analyses can well be illustrated by the $\mathrm{Cr}$ concentrations reported for blood, which have ranged from 1000 to $0.72 \mu \mathrm{g} \mathrm{Cr} / 1$ (Mertz, 1975).

$\mathrm{Cr}$ metabolism also illustrates the differences in biological effectiveness which can occur between various chemical forms of an element. Inorganic $\mathrm{Cr}$ can exist in several valency states, of which only the trivalent form is biologically active, but even this is far less active than $\mathrm{Cr}$ in the form of glucose tolerance factor (GTF) (Hambidge, 1974). The latter is a low-molecular-weight compound which contains $\mathrm{Cr}$ co-ordinated to two nicotinic acid molecules with the remaining co-ordination sites protected by amino acids (Mertz, 1974). It appears to act as a cofactor for insulin and to be responsible for the essentiality of Cr. Toepfer, Mertz, Roginsky \& Polansky (1973) showed that the biological effectiveness of various dietary sources of $\mathrm{Cr}$ did not correlate with their total $\mathrm{Cr}$ content and suggested that this discrepancy resulted from variations in the proportion of $\mathrm{Cr}$ present as GTF. The Cr content of ethanol extracts of the foodstuffs did, however, correlate significantly with GTF activity and may prove to be a useful criterion in assessing dietary $\mathbf{C r}$ status. This situation is similar to that of $\mathrm{Co}$, which must be supplied to man as vitamin $B_{12}$. V may also merit consideration in this context: in growth experiments, the most active inorganic form was orthovanadate (Schwarz, 1974b) but in animals, V is found mainly in fat (Schroeder, Balassa \& Tipton, I 963 ). The possibility exists that $\mathrm{V}$ forms part of a lipid-soluble molecule whose biological activity is much greater than that of orthovanadate.

\section{Factors affecting availability of trace elements}

A major modifier of availability of $\mathrm{Cu}, \mathrm{Fe}, \mathrm{Mn}$ and $\mathrm{Zn}$ is phytic acid, which is widely distributed in plant products, especially plant seeds. It appears to form insoluble salts with these trace elements in the gut, thus rendering them unavailable for absorption (Davies \& Nightingale, 1975). In the Middle East, human $\mathrm{Zn}$ deficiency does not appear to be associated with low $\mathrm{Zn}$ intakes but has been ascribed partially to consumption of unleavened bread rich in phytic acid (Reinhold, Parsa, Karimian, Hammick \& Ismail-Beigi, 1974). Recent research (N. T. Davies, personal communication) has suggested that where phytic acid is a contributory factor in the development of $\mathrm{Zn}$ deficiency a 'vicious circle' may operate. The enzyme responsible for the destruction of phytic acid in the gut, phytase (myo-inositol-hexaphosphate phosphohydrolase; $E C$ 3.I.3.8), appears to be a $\mathrm{Zn}$-enzyme whose activity depends on dietary $\mathrm{Zn}$ availability. Reduction in the latter will tend therefore to decrease phytase activity in the gut, reduce phytic acid destruction and thereby further increase the formation of unavailable $\mathrm{Zn}$ salts. The reduced availability of $\mathrm{Zn}$ in Middle-Eastern diets cannot, however, be explained 
solely on the basis of their content of phytic acid, and Reinhold (1975) has suggested that fibre in the diet may bind $\mathrm{Zn}$ and prevent its uptake by the intestine. A similar reduction in availability of $\mathrm{Zn}$ caused by additions of cellulose to rat diets has been observed (Becker \& Hoekstra, I97I).

In addition to effects caused by organic constituents of the diet, a variety of interactions between the trace elements can alter their availability or metabolism (reviewed by Davies, I 974). Evidence for these interactions comes mainly from animal experimentation but such an interaction may underlie the proposed relationship between dietary $\mathrm{Zn}: \mathrm{Cu}$ ratios and the incidence of coronary heart disease (Klevay, 1975). Additionally Deosthale \& Gopalan (1974) have shown that urinary $\mathrm{Cu}$ excretion in man increases with increasing Mo intake from sorghum, and Agarwal (1975) has suggested that, in association with high $\mathrm{F}$ intakes, a Moinduced $\mathrm{Cu}$ deficiency causes a crippling disease characterized by genu valgum in communities of Southern India where sorghum is part of the staple diet.

Finally, cooking and preserving processes must be considered in assessing trace element availability, since essentially these may consist of hot aqueous extraction of the food or treatment of it with dilute solutions of minerals derived from the cooking vessel, either of which may dramatically alter the trace-metal content of the basic food (Wysokińska, I967; Schroeder, 1971).

\section{Human trace element deficiencies, past and prospective}

The advantages of large-scale supplementation with F, Fe and I are recognized and the need to correct other trace element deficiencies has been stressed above, yet emphasis has also been placed on some of the inadequacies of current methods of assessing trace element status. Despite those limitations, however, screening for trace element concentrations in plasma and hair has already led to a cure for acrodermatitis enteropathica (Moynahan, 1974) and to recognition of $\mathrm{Zn}$ responsive syndromes in children (Hambidge et al. 1972). In future two factors may tend to increase the incidence of dietary $\mathrm{Zn}$ deficiency. First, there is a continuing trend towards the consumption of processed and refined foods which often have reduced trace element contents (e.g. whole-wheat bread $490 \mu \mathrm{g} \mathrm{Zn} / \mathrm{MJ}$, white bread $9^{8} \mu \mathrm{g} \mathrm{Zn} / \mathrm{MJ}$; Mills, 1973b). Secondly it is likely that economic pressures will lead to increased use of meat substitutes based on plant protein sources. Since in the past much of the available dietary $\mathrm{Zn}$ has been derived from meat products, reduction in their consumption will tend to reduce $\mathrm{Zn}$ intakes and, although meat substitutes may be equally rich in $\mathrm{Zn}$, they often contain phytic acid. Trace element enrichment of manufactured plant protein sources may therefore prove to be advantageous.

Recognition of the involvement of trace elements in human disorders has also come from consideration of the implications for human medicine of results obtained with experimentally induced deficiencies in animals. Thus the finding of impaired glucose tolerance in $\mathrm{Cr}$-deficient rats led to $\mathrm{Cr}$ supplementation of diabetic patients, which resulted in a return to normal tolerance levels in almost half the cases of maturity-onset diabetes investigated (reviewed by Hambidge, 1971). Diabetes is a common ailment and, if future studies show that some of the 
unresponsive cases are cured when $\mathrm{Cr}$ can be given as GTF, the importance of $\mathrm{Cr}$ in the nutrition of the elderly could be considerable.

Because of the ethical problems of inducing trace element deficiencies in man, their future recognition will continue to depend heavily, until more reliable diagnostic procedures are developed, on the integration of clinical experience and a knowledge of the signs of trace element imbalances in animals. Thus the realization that errors in $\mathrm{Cu}$ metabolism are involved in Menke's syndrome began with the recognition of similarities between the hair of patients with this disease and the wool of $\mathrm{Cu}$-deficient sheep (Danks, Stevens, Campbell, Gillespie, WalkerSmith, Blomfield \& Turner, 1972). Recently Carlisle (1974) has demonstrated a range of abnormalities of connective tissue, cartilage and bone formation in $\mathrm{Si}$ deficient chicks and $\mathrm{Si}$ has been shown to be a constituent of mucopolysaccharides (Schwarz, 1974a). Dietary intake of mucopolysaccharides is largely from connective tissues which are avoided in the diet of fastidious Western societies and contamination of food with Si from the outer layers of plant products has almost certainly declined in these societies. Tissue concentrations of $\mathrm{Si}$, like those of $\mathbf{C r}$, decline with age (Schroeder, Balassa \& Tipton, 1962; Carlisle, 1974) and the possibility of diseases associated with natural deficiencies of $\mathrm{Si}$ should be considered (Carlisle, 1974; Schwarz, r974a). Studies of $\mathrm{Cu}$ deficiency in animals have shown that $\mathrm{Cu}$ is involved in the cross-linking of elastin and collagen and that deficiencies of $\mathrm{Cu}$ can result in bone rarefaction and cardiovascular lesions (Waisman, Cancilla \& Coulson, 1969; Mills et al. 1976). In view of the marginal adequacy of $\mathrm{Cu}$ intakes, investigation of the possible involvement of $\mathrm{Cu}$ in human diseases of elastin and collagen may merit further study.

Past experience and the growing body of knowledge on trace elements suggest that they should not be ignored when considering adequacy of diets and that in future it will be recognized that they play a more important and widespread role in human health than has previously been suggested.

Agarwal, A. K. (1975). New Scient. 65, 260.

\section{REFERENCES}

Arakawa, T., Tamura, T., Igarashi, Y., Suzuki, H. \& Sandstead, H. H. (1975). In Abstracts of $x$ th International Congress of Nutrition, p. 235 [H. Koishi, N. Hosoya and K. Yasumoto, editors]. Kyoto: Science Council of Japan.

Becker, W. M. \& Hoekstra, W. G. (1971). In Intestinal Absorption of Metal Ions, Trace Elements and Radionuclides, p. 229 [S. C. Skoryna and D. Waldron-Edward, editors]. Oxford and New York: Pergamon Press.

Beisel, W. R., Pekarek, R. S. \& Wannemacher, R. W. Jr (1974). In Trace Element Metabolism in Animals, P. 217 [W. G. Hoekstra, J. W. Suttie, H. E. Ganther and W. Mertz, editors]. Baltimore, Maryland: University Park Press.

Briggs, M. H., Briggs, M. \& Austin, J. (1971). Nature, Lond. 232, 480.

Burch, R. E., Hahn, H. K. J. \& Sullivan, J. F. (1975). Clin. Chem. 21, 5or.

Carlisle, E. M. (1974). Fedn Proc. Fedn Am. Socs exp. Biol. 33, $175^{8}$.

Cartwright, G. E., Markowitz, H., Shields, G. S. \& Wintrobe, M. M. (1960). Am. F. Med. 28, 555.

Danks, D. M., Cartwright, E., Stevens, B. J. \& Townley, R. R. W. (1973). Science, N.Y. 179, II 40.

Danks, D. M., Stevens, B. J., Campbell, P. E., Gillespie, J. M., Walker-Smith, J., Blomfield, J. \& Turner, B. (1972). Lancet i, 1100.

Davies, N. T. (1974). Proc. Nutr. Soc. 33, 293.

Davies, N. T. \& Nightingale, R. (1975). Br. Y. Nutr. 34, 243.

Deosthale, Y. G. \& Gopalan, C. (1974). Br. F. Nutr. 3I, 35 I. 
Fleming, C. R., Hodges, R. E., Smith, L. M. \& Hurley, L. S. (1975). In Abstracts of xth International Congress of Nutrition, p. 235 [H. Koishi, N. Hosoya and K. Yasumoto, editors]. Kyoto: Science Council of Japan.

Graham, G. G. \& Cordano, A. (1969). Johns Hopkins med. J. 124 , I 39.

Halstead, J. A. \& Smith, J. C. (1970). Lancet i, 322.

Hambidge, K. M. (1974). Am. f. clin. Nutr. 27, 505.

Hambidge, K. M. \& Droegemueller, W. (1974). Obstet. Gynec., N.Y. 44, 666.

Hambidge, K. M., Hambidge, C., Jacobs, M. \& Baum, J. D. (1972). Pediat. Res. 6, 868.

Henkin, R. I. (1971). In Newer Trace Elements in Nutrition, p. 256 [W. Mertz and W. E. Cornatzer, editors]. New York: Marcel Dekker Inc.

Henkin, R. I. (1974). New Engl. J. Med. $291,675$.

Hytten, F. E. \& Leitch, 1. (1964). The Physiology of Human Pregnancy. Oxford: Blackwell.

Klevay, L. M. (1975). Nutr. Rep. int. 11, 237.

Lindeman, R. D., Bottomley, R. G., Cornelison, R. L. \& Jacobs, L. A. (1972). F. Lab. clin. Med. $79,45^{2}$.

Mertz, W. (1974). Proc. Nutr. Soc. 33, 307.

Mertz, W. (1975). Clin. Chem. $21,468$.

Mills, C. F. (1973a). In Therapeutic Aspects of Nutrition, p. 14 [J. H. P. Jonxis, H. K. A. Visser and J. A. Troelstra, editors]. Leiden: Stenfert Kroese.

Mills, C. F. (1973b). In Nutritional Deficiencies in Modern Society, p. 56 [A. N. Howard and I. M. Baird, editors]. London: Newman Books Ltd.

Mills, C. F., Dalgarno, A. C. \& Wenham, G. (1976). Br. F. Nutr. 35, 309.

Moynahan, E. J. (1974). Lancet ii, 399.

National Research Council (1971). Nutrient Requirements of Poultry, 6th ed., p. 17. Washington, DC: National Academy of Sciences.

National Research Council (1972). Nutrient Requirements of Laboratory Animals, 2nd ed., p. 56. Washington, DC: National Academy of Sciences.

National Research Council (1974). Recommended Dietary Allowances, 8th ed., p. 91. Washington, DC: National Academy of Sciences.

Nielsen, F. H. \& Sandstead, H. H. (1974). Am. Y. clin. Nutr. 27, 515.

Okada, A., Takagi, Y., Itakura, F., Satani, M., Manabe, H. \& Ilda, Y. (1975). In Abstracts of xth International Congress of Nutrition, p. 236. [H. Koishi, N. Hosoya and K. Yasumoto, editors]. Kyoto: Science Council of Japan.

O'Leary, J. A. \& Spellacy, W. N. (1968). Science, N.Y. 162, 682.

Osis, D., Kramer, L., Wiatrowsti, E. \& Spencer, H. (1972). Am. Y. clin. Nutr. $25,582$.

Pories, W. J., Henzel, J. H., Rob, C. G. \& Strain, W. H. (1967). Lancet i, 121.

Reinhold, J. G. (1975). Clin. Chem. 21, 476.

Reinhold, J. G., Parsa, A., Karimian, N., Hammick, J. W. \& Ismail-Beigi, F. (1974). J. Nutr. 104, 976.

Ricour, C., Gros, J., Maziere, B. \& Comar, D. (1975). In Abstracts of xth International Congress of Nutrition, p. $23^{6}$ [H. Koishi, N. Hosoya and K. Yasumoto, editors]. Kyoto: Science Council of Japan.

Sandstead, H. H. (1973). Am. Y. clin. Nutr. 26, 125 I.

Scheinberg, 1. H., Cook, C. D. \& Murphy, J. A. (1954). J. clin. Invest. 33, 963 .

Schroeder, H. A. (1971). Am. F. clin. Nutr. 24, $5^{62}$.

Schroeder, H. A., Balassa, J. J. \& Tipton, 1. H. (1962). J. chron. Dis. 15, 941.

Schroeder, H. A., Balassa, J. J. \& Tipton, I. H. (1963). F. chron. Dis. 16, 1047.

Schroeder, H. A., Balassa, J. J. \& Tipton, I. H. (1964). J. chron. Dis. 17, 483.

Schroeder, H. A., Nason, A. P., Tipton, I. H. \& Balassa, J. J. (I g66). J. chron. Dis. 19, 1007.

Schwarz, K. (1974a). In Trace Element Metabolism in Animals, p. 406 [W. G. Hoekstra, J. W. Suttie, H. E. Ganther and W. Mertz, editors]. Baltimore, Maryland: University Park Press.

Schwarz, K. (1974b). Fedn Proc. Fedn Am. Socs exp. Biol. 33, 1748.

Sussman, M. (1974). In Iron in Biochemistry and Medicine, P. 649 [A. Jacobs and M. Worwood, editors]. London and New York: Academic Press.

Toepfer, W. W., Mertz, W., Roginsky, E. E. \& Polansky, M. M. (1973). J. agric. Fd Chem. $21,69$.

Underwood, E. J. \& Somers, M. (1969). Aust. F. agric. Res. 20, 889.

Waisman, J., Cancilla, P. A. \& Coulson, W. F. (1969). Lab. Invest. 2 1, 548.

Wiener, G. \& Field, A. C. (1969). F. comp. Path. Ther. 79, 7.

WHO (1973). Tech. Rep. Ser. Wid Hlth Org. no. 532.

Wysokinska, Z. (1967). Quoted by Nutrition Abstracts and Reviews (1971). Nutr. Abstr. Rev. 4I, 1196.

\section{Printed in Great Britain}

